UDC 621

LBC 31.15

\title{
WAYS TO REDUCE ENERGY COSTS IN POULTRY FARMS
}

\author{
Aleksey V. Sklyar \\ OOO "Big Dutchman", Moscow, Russian Federation; \\ Big Dutchman AG (holding) Auf der Lage, Vechta, Germany \\ Margarita V. Postnova \\ Volgograd State University, Volgograd, Russian Federation
}

\begin{abstract}
Currently, the modern poultry farms are located in regions with different climatic conditions. Thus, the component of the electric power being the base for combined heating and ventilating systems, lighting, and local heating of poultry farms, is great in power engineering on the territory of the Russian Federation. The analysis of energy costs of poultry farms showed that of the estimated options for reducing the cost of electricity for poultry farms, one of the most effective can be an alternative source such as the generation of own electricity. Naturally, for biological production with a continuous technological cycle (poultry farming, for example), seems to be replace about $45-55 \%$ of the needs of the factory and serve as a reserve for the rest, but not cover all $100 \%$ of needs.

Key words: poultry farms, electricity, energy costs, engines, climate.
\end{abstract}

УДК 621

ББК 31.15

\section{ПУТИ СНИЖЕНИЯ ЗАТРАТ НА ЭЛЕКТРОЭНЕРГИЮ В ПТИЦЕХОЗЯЙСТВАХ}

\section{Алексей Владимирович Скляр}

ООО «Биг Дачмен», г. Москва, Российская Федерация;

Big Dutchman AG (холдинг), Vechta, Германия

\section{Маргарита Викторовна Постнова}

Волгоградский государственный университет, г. Волгоград, Российская Федерация

\begin{abstract}
Аннотация. В настоящее время современные птицеводческие хозяйства размещаются в регионах с различными климатическими условиями. Таким образом, в энергетике велика составляющая электроэнергии, на которой базируются совмещенные отопительно-вентиляционные системы, освещение и локальный обогрев птицефабрик на территории РФ. Анализ энергозатрат птицефабрик показал, что из оцениваемых вариантов удешевления электроэнергии для птицеводческих хозяйств, одним из наиболее эффективных мо$\infty$ жет быть альтернативный источник такой как выработка собственной электроэнергии. Естественно, для биологического производства с непрерывным технологическим циклом, каким является птицеводческое хозяйคे ство, речь не идет о 100 \% замещении электросетей - они остаются закрывать 45-55 \% потребностей фабрики $\sum$ и служить резервом остальному.
\end{abstract}

Ключевые слова: птицеводческие хозяйства, электроэнергия, энергетические затраты, двигатели, климат.

Одной из специфических особенностей птицеводства РФ является размещение птицеводческих хозяйств в регионах с очень различающимся климатом. По СНиП 23-01-99: если в городе Сочи отопительный сезон - 98 суток с влажным субтропическим воздухом, то в городе Ростове-на-Дону - 167 суток при невысокой влажности притока, в центре европейской части страны в городе Воронеже - 196 суток, а за Полярным кругом в городе Мурманс- 
ке - 269 суток, в г. Магадане на вечной мерзлоте - 258 суток, в Сибири (города Томск и Красноярск и др.) - 236-275 сут. при очень низких температурах наружного воздуха и на Дальнем Востоке в городе Хабаровске 211 суток при достаточно холодной зиме [4]. Самое «холодноширотное» в мировой практике птицеводство требует существенных энергетических затрат и не случайно энергетика в наших хозяйствах занимает третью позицию в себестоимости яиц и мяса птицы (до 12-14 \%) $[3 ; 6]$. В свою очередь в энергетике велика составляющая электроэнергии, на которой базируются совмещенные отопительно-вентиляционные системы, освещение и локальный обогрев (брудера и пр.). Бройлерная птицефабрика с замкнутым циклом производства на 12 14 тыс. т мяса в живой массе расходует 7691230 кВт·ч/т продукции (например, Шекснинская бройлерная п/ф Вологодской обл. - 16 млн кВт·ч/год). Постоянный рост стоимости исходного топлива электростанций (газ, уголь. нефть и др.) обусловливает непрерывное прогрессирующее нарастание цены киловатт-часа.

В период разделения РАО-ЕЭС реформа электроэнергетики РФ связывалась с созданием для потребителя в рыночных условиях возможности покупать кВт.ч по меньшим ценам, чем это было в старой структуpe РАО-ЕЭС и при этом назывались варианты дифференциации цен на таком рынке:

- многотарифность-многозонность учета электроэнергии (разница в цене кВт-ч по времени суток) с внедрением АИИСКУЭ (Автоматизированная информационно-измерительная система коммерческого учета электроэнергии) [1];

- выбор-смена гарантирующего поставщика;

- переход хозяйства на прием электроэнергии по высокому напряжению (10, 35, 110 кВ);

- выход птицеводческого хозяйства на оптовый рынок электроэнергии (далее ОРЭМ);

- выработка птицеводческим хозяйством собственной электроэнергии с использованием доступного недорогого топлива (сетевой газ, биогаз из помета, сырая нефть, нативный и подстилочный помет и проч.).

Аналитическая оценка и мероприятия по практической реализации названных вариантов (выполнялись совместно с инженерными службами ряда птицеводческих хозяйств) показали, что:

a) по тарифам и зонам суточного учета - специфика технологии птицеводческих хозяйств такова, что возможности переноса на ночные часы работы токоприемников, использующихся днем, невелики по объемам (холодильники, заполнение резервуаров воды, но это до 1,5 \% общих мощностей). Убой птицы, работа яйцесклада, выработка кормов в ночные часы требуют повышенной оплаты персонала (в Европе выходные, праздники и ночные смены - по двойным тарифам) с затратами выше энергоэкономии;

б) по смене поставщика и приему энергии на высоком напряжении. Такие изменения практически невозможно реализовать - частным электросетям выгодно оставаться постоянными поставщиками у местных потребителей и не терять собственность, регулярно несущую прибыль;

в) по ОРЭМ. Выход на оптовый рынок по положению об ОРЭМ возможен лишь для крупных потребителей - для регистрации в ОРЭМ птицеводческое хозяйство должно иметь не менее 20 тыс. кВт общей присоединенной мощности при не менее 750 кВт каждой точки и выстроенной АИИСКУЭ [1]. И потому с 20.06.2014 г., когда вводились эти нормы, в Палату покупателей ОРЭМ из 89 предприятий не вошло ни одно птицеводческое хозяйство, К этому надо добавить, что на сегодня внедрение рыночных отношений в электроэнергетику по объективным причинам не повсеместно - на Дальнем Востоке, в городе Архангельске, Республике Коми и г. Калининграде - электричество поставляется по регулируемым ценам, а в Восточной Сибири энергорынок пока трудно организовать при имеющейся структуре энергосистем [2];

г) по выработке птицеводческим хозяйством собственной электроэнергии (альтернативный источник).

Для практической оценки схемы на базе Череповецкой бройлерной фабрики (далее ЧПФ) при газовой котельной была построена первая в птицеводческих хозяйствах РФ миниэлектростанция (далее - МЭС) для выработки собственной электроэнергии - на машзаводе был изготовлен электрогенератор мощностью 1,25 МВт в комплекте с паровой турбиной. Эта 
схема была взята за основу исходя из того, что в котельной из трех котлов ДКВр-20-13ГМ один имел неполную загрузку и свободной мощности было достаточно для того, чтобы питать названную турбину. Десятилетний опыт эксплуатации этого цеха с годовой выработкой 3,0 млн. кВт·ч/год (это $32 \%$ объема п/ф) показал, что себестоимость 1 кВт·ч, вырабатываемого такой установкой в 2,63,2 раза ниже цены сетевого (это снижало годовую оплату за электроэнергию на 20 \% в целом по фабрике [5]. Если производить в хозяйстве половину электричества, то платежи уменьшатся на третью часть энергозатрат).

Таким образом, можно сделать вывод, что из оцениваемых вариантов удешевления электроэнергии для птицеводческих хозяйств, одним из наиболее эффективных может быть альтернативный источник, выработка собственной электроэнергии. Естественно, для биопроизводства с непрерывным технологическим циклом, каким является птицеводческое хозяйство, речь не идет о $100 \%$ замещении электросетей - они остаются закрывать 45-55 \% потребностей фабрики и служить резервом остальному (учитывая, что низковольтная часть везде осталась у фабрик, то сетям этого достаточно для обновления ТП и ЛЭП высокого напряжения).

Производственная проверка МЭС позволила также обосновать ряд требований к таким станциям.

В МЭС основой должна быть не турбина (в том числе газовая), а газо-поршневой двигатель (далее ГПД). У него выше КПД, изменение нагрузки и внешних температур на его КПД не влияет как у турбин, на запуск ГПД требуется 2-3 минуты (у турбины в 5 раз дольше), число пусков ГПД не ограничено и не влияет на его ресурс, ГПД работает при давлении газа от 150 мбар до 3000 мбар (у турбин ниже ресурс), у ГПД на 21 \% ниже капитальные затраты.

Перед дизелями у ГПД преимущество более дешевое топливо и втрое меньшие выбросы $\mathrm{NO}_{\mathrm{x}}$, не случайно последующие варианты МЭС на птицефабриках были построены именно с применением ГПД (п/ф «Среднеуральская», «Роскар» и др.).

Поскольку цеха птицеводческих хозяйств по ветеринарным требованиям разнесены на зоны (от 300 м и более) надо децентрализиро- вать МЭС и ставить локальные контейнерноблочные МЭС для крупных зон, привязывая их к фабричным низковольтным сетям с конкретной мощностью, обеспечивающей нагрузки определенной зоны (на ЧПФ для распределения мощности МЭС в 1,25 МВт по цехам, удаленным на $0,5-1,2$ км, использовались сетевые ТП-10/0,4 и ЛЭП-10, что вызвало проблему по учету и оплате перетоков электроэнергии, произведенной сетями и фабрикой по общему каналу ТП-ЛЭП10-ТП).

В случае затруднений по лимитам на газ для МЭС, в последней могут использоваться двигатели, работающие на ином доступном топливе, для этого машиностроительной промышленностью РФ разработаны двигатели на сырой нефти. Первые из них успешно эксплуатируются также более десяти лет на нефтепромыслах Восточной Сибири.

\section{СПИСОК ЛИТЕРАТУРЫ}

1. Автоматизированная информационно-измерительная система коммерческого учета электроэнергии. - Электрон. текстовые дан. - Режим доступа: https://dic.academic.ru/dic.nsf/ruwiki/ 1276023 (дата обращения: 30.11.2018).

2. Мамедов, Э. С. Моделирование энергосберегающей технологии в животноводстве и птицеводстве / Э. С. Мамедов // Аграрная наука. - 2013. № 1. - C. 31-32.

3. Маркелова, Е. К. Энергозатраты на производство продукции птицеводства, основные направления их снижения / Е. К. Маркелова, Р. В. Тузова // Труды международной научно-технической конференции. Энергообеспечение и энергосбережение в сельском хозяйстве - 2018. - Т. 1.C. 286-294.

4. Система нормативных документов в строительстве. Строительные нормы и правила РФ. Строительная климатология. СНиП 23-01-99. - Электрон. текстовые дан. - Режим доступа: http:// gostrf.com/norma_data/7/7001/index.htm (дата обращения: 30.11.2018).

5. Тихомиров, А. В. Основные направления модернизации энергетической базы села и повышения энергоэффективности сельхозпроизводства / А. В. Тихомиров // Международный агроэкологический форум : сборник. - 2013. -C. 156-163.

6. Электроемкость продукции промышленного птицеводства / Г. П. Ерошенко, И. Ю. Лошкарев, И. В. Шестаков, В.И. Лошкарев // Аграрный журнал. - 2016. - № 2. - С. 48-50 


\section{Information about the Authors}

Aleksey V. Sklyar, Candidate of Sciences (Agriculture), Official Agent, Big Dutchman AG (holding) Auf der Lage 249377 Vechta-Calveslage Postfach 116349360 Vechta, Germany, vsklar41@mail.ru.

Margarita V. Postnova, Doctor of Biological Sciences, Chief, Department of Bioengineering and Bioinformatics, Volgograd State University, Prosp. Universitetskiy, 100, 400062 Volgograd, Russian Federation,postnova@volsu.ru.

\section{Информация об авторах}

Алексей Владимирович Скляр, кандидат сельскохозяйственных наук, представитель, OОO «Биг Дачмен», г. Москва, Российская Федерация; Big Dutchman AG (холдинг) Auf der Lage 249377 Vechta-Calveslage Postfach 116349360 Vechta, Германия, vsklar41@mail.ru.

Маргарита Викторовна Постнова, доктор биологических наук, старший научный сотрудник, заведующая кафедрой биоинженерии и биоинформатики, Волгоградский государственный университет, 400062 г. Волгоград, Российская Федерация, postnova@volsu.ru. 